PYTHAGORAS: Jurnal Pendidikan Matematika

Volume 10 - Nomor 2, Desember 2015, (179-188)

Available online at: http://journal.uny.ac.id/index.php/pythagoras

\title{
Perbandingan antara Keefektifan Model Guided Discovery Learning dan Project-Based Learning pada Matakuliah Geometri
}

\author{
Okky Riswandha Imawan \\ Pendidikan Matematika, Universitas Cenderawasih. Jalan Kampus Baru Kompleks Uncen Waena \\ Abepura, Indonesia. Email: okkyriswandhaimawan@gmail.com
}

\begin{abstract}
Abstrak
Penelitian ini bertujuan untuk mendeskripsikan keefektifan dan perbedaan keefektifan antara model Guided Discovery Learning (GDL) dan model Project- Based Learning (PjBL) ditinjau dari prestasi belajar, kepercayaan diri, dan keterampilan berpikir kritis mahasiswa pada matakuliah geometri ruang. Jenis penelitian ini adalah kuasi eksperimen. Subjek penelitian ini adalah dua kelas mahasiswa Program Studi Pendidikan Matematika Universitas Ahmad Dahlan semester 2 yang dipilih secara acak. Analisis data untuk menguji keefektifan model GDL dan model PjBL ditinjau dari masing-masing variabel terikat menggunakan Uji $t$. Sedangkan teknik analisis data untuk menguji perbedaan antara keefektifan model GDL dan model PjBL menggunakan Uji MANOVA. Hasil penelitian menunjukkan bahwa, ditinjau dari prestasi belajar, kepercayaan diri, dan keterampilan berpikir kritis mahasiswa diketahui bahwa penerapan model GDL pada matakuliah Geometri Ruang efektif, penerapan Model PjBL pada matakuliah Geometri Ruang efektif, dan tidak terdapat perbedaan keefektifan model GDL dan model PjBL pada matakuliah Geometri Ruang.

Kata Kunci: model guided discovery learning, model project-based learning, prestasi belajar, kepercayaan diri, keterampilan berpikir kritis

\section{The Comparisons Between the Effectiveness of the Guided Discovery Learning Model and Project-Based Learning Model on Solid Geometry Subjects}

Abstract

This research aims to describe the effectiveness and effectiveness differences of the Guided Discovery Learning (GDL) Model and the Project Based Learning (PjBL) Model in terms of achievement, self-confidence, and critical thinking skills of students on the Solid Geometry subjects. This research was quasi experimental. The research subjects were two undergraduate classes of Mathematics Education Program, Ahmad Dahlan University, in their second semester, established at random. The data analysis to test the effectiveness of the GDL and PjBL Models in terms of each of the dependent variables used the t-test. The data analysis to test differences between effectiveness of the GDL and that of the PJBL Model used the MANOVA test. The results of this research show that viewed from achievement, self confidence, and critical thinking skills of the students are the application of the GDL Model on Solid Geometry subject is effective, the application of the PjBL Model on Solid Geometry subject is effective, and there is no difference in the effectiveness of GDL and PjBL Models on Solid Geometry subject in terms of achievement, self confidence, and critical thinking skills of the students.
\end{abstract}

Keywords: guided discovery learning model, project-based learning model, achievement, selfconfidence, critical thinking skills

How to Cite Item: Imawan, O. (2015). Perbandingan antara keefektifan model guided discovery learning dan project-based learning pada matakuliah geometri. PYTHAGORAS: Jurnal Pendidikan Matematika, 10(2), 179188. doi:http://dx.doi.org/10.21831/pg.v10i2.9156 


\section{Pythagoras, 10 (2), Desember 2015 - 180}

Okky Riswandha Imawan

\section{PENDAHULUAN}

Sebagai calon guru mata pelajaran matematika di tingkat sekolah menengah, mahasiswa program studi pendidikan matematika harus menguasai materi yang akan dipelajari oleh calon peserta didiknya. Pentingnya penguasaan materi adalah untuk menunjang kompetensi profesionalisme seorang guru. Hal ini didukung oleh hasil penelitian yang dilakukan oleh Linguistika, Listyani, \& Retnawati (2013, p.1) yang menunjukkan bahwa terdapat hubungan yang berarti antara penguasaan materi guru matematika kelas XII program IPS dengan prestasi belajar peserta didik. Dari pendapat Hudojo (1988, p.144), Winkel (1996, p.41), Sudjana (2006, p.22), Boyd \& Bee (2009, p.259), serta Nitko \& Brookhart (2011, p.497), dapat dijelaskan bahwa prestasi belajar menunjukkan pemahaman dan penguasaan materi yang dipelajari seseorang sebagai bukti keberhasilannya dalam belajar.

Terdapat hal penting lainnya bagi calon guru mata pelajaran matematika, yaitu mahasiswa program studi pendidikan matematika harus memiliki kepercayaan diri yang tinggi. Hal tersebut didukung oleh Tan (2007, p.67) yang menyatakan bahwa kepercayaan diri penting agar seseorang dapat menjalankan tugasnya dengan baik pada masyarakat. Dari pendapat McElmeel (2002, p.27), McPheat (2010, p.14), serta Lauster (Ghufron \& Risnawati S, 2010, p.34), dapat dijelaskan bahwa kepercayaan diri adalah keyakinan seseorang terhadap kemampuannya sendiri tanpa ketergantungan kepada orang lain, bertindak sesuai kehendak-nya, optimis dengan tindakan yang dilakukan-nya, dan bertanggung jawab terhadap konse-kuensi dari tindakan yang dilakukannya.

Hal lainnya yang tidak kalah penting dibandingkan pemahaman terhadap materi dan kepercayaan diri bagi calon guru mata pelajaran matematika yaitu keterampilan berpikir kritis. Menurut Feldman (2010, p.4) salah satu manfaat keterampilan berpikir kritis adalah untuk mengembangkan solusi terbaik untuk suatu masalah. Selain itu, penelitian Taghva, Rezaei, \& Ghaderi (2014, p.7) menunjukkan bahwa terdapat hubungan yang signifikan antara keterampilan berpikir kritis seorang guru dengan prestasi belajar peserta didiknya. Hal ini mengisyaratkan bahwa jika ingin peserta didiknya memiliki prestasi belajar yang baik dan keterampilan berpikir kritis yang tinggi maka guru atau dosennya harus telah memiliki keterampilan berpikir kritis yang tinggi.

Dari pendapat Glazer (2001, p.13), Epstein \& Kernberger (2006, p.5), Gambrill \& Gibb (2009, p.15), Arends \& Kilcher (2010, p.233), serta Starkey (2010, p.vii), dapat dijelaskan bahwa keterampilan berikir kritis adalah keterampilan dalam menganalisis kebenaran dari suatu konsep, keterampilan untuk mengenali kesalahan atau bias dari langkah-langkah penemuan konsep, dan menerapkan konsep untuk menyelesaikan permasalahan baru.

Sementara itu, salah satu materi penting yang dipelajari oleh mahasiswa program studi pendidikan matematika adalah geometri. Terdapat beberapa macam ranah geometri yaitu geometri bidang (plane geometry) dan geometri ruang (solid geometry). Geometri berkaitan erat dengan kehidupan sehari-hari, sehingga tidak jarang muncul permasalahan dalam kehidupan sehari-hari yang berhubungan dengan geometri dan membutuhkan penerapan konsep geometri untuk menyelesaikannya. Materi geometri, khususnya geometri ruang telah dipelajari peserta didik sejak berada di bangku sekolah menengah. Akan tetapi, kandungan materi gemoetri ruang yang dipelajari oleh peserta didik di tingkat mahasiswa lebih mendalam dibandingkan yang dipelajari di tingkat sekolah menengah.

Berdasarkan kajian teori, terdapat berbagai model pembelajaran yang diperkirakan cocok terhadap kakakteristik mahasiswa dan diperkirakan efektif untuk meningkatkan prestasi belajar (PB), kepercayaan diri (KD), dan keterampilan berpikir kritis (KBK) mahasiswa, diantaranya adalah model Guided Discovery Learning (GDL) dan Project Based Learning (PjBL). Menurut Syah (2014, p.243), secara umum langkah-langkah kegiatan pembelajaran dalam model GDL yaitu: (1) stimulation (pemberian rangsangan informasi); (2) problem statement (identifikasi masalah), (3) data collection (pengumpulan data); (4) data processing (pengolahan data); (5) verification (pemeriksaan kembali); dan (6) generalization (pembuatan kesimpulan).

Hasil penelitian yang dilakukan oleh Sulistyowati, Widodo, \& Sumarni (2012, p.1) menunjukkan bahwa model GDL dapat meningkatkan keterampilan pemecahan masalah peserta didik, dimana keterampilan pemecahan masalah merupakan salah satu jenis keterampilan berpikir tingkat tinggi. Selain itu, hasil penelitian Udo (2011, p.238), Prihantomo (2012, p.x), serta Akanmu \& Fajemidagba (2013, p.85), 
menunjukkan bahwa model GDL efektif ditinjau dari prestasi belajar peserta didik. Di samping itu, Hasil penelitian Tran, Nguyen, Bui, \& Phan (2014, p.56) mendukung kajian teori penelitian ini yang memperkirakan bahwa penerapan model GDL efektif ditinjau kepercayaan diri peserta didik, khususnya pada indikator yang berhubungan dengan kemandirian peserta didik.

Sementara itu, menurut Abidin (2014, p.172), secara umum langkah-langkah model PjBL yaitu: (1) tahap praproyek (merencanakan alternatif proyek beserta hal-hal pendukung proyek); (2) tahap 1: mengidentifikasi masalah (Mengidentifikasi masalah dan membuat rumusan masalah); (3) tahap 2: membuat desain dan jadwal pelaksanaan proyek; (4) tahap 3: melaksanakan penelitian awal (mencari spesifikasi terbaik untuk produk yang hendak dibuat); (5) tahap 4: menyusun draft/prototype produk; (6) tahap 5: menilai dan memperbaiki produk (presentasi dan penilaian terhadap produk yang telah dibuat); (7) tahap 6: finalisasi dan publikasi produk (perbaikan dan publikasi produk); dan (8) tahap pasca-proyek (penilaian terhadap penguasaan konsep peserta didik).

Dalam tulisan Thomas (2000, p.17), dijelaskan bahwa selain dapat meningkatkan keterampilan peserta didik dalam memecahkan masalah, model PjBL juga dapat meningkatkan prestasi belajar peserta didik yang diukur dengan tes. Hasil penelitian Ozdemir (2006, p.v) menunjukkan bahwa model PjBL meningkatkan prestasi geometri mahasiswa dan sikapnya terhadap geometri. Penelitian lainnya yang mendukung kajian teori penelitian ini yaitu penelitian yang dilakukan oleh Filcik, Bosch, Pederson, \& Haugen (2012, p.1), yang hasilnya menunjukkan bahwa model PjBL efektif ditinjau dari aspek pengetahuan konseptual. Keefektifan model pembelajaran dalam penelitian ini ditinjau dari $\mathrm{PB}, \mathrm{KD}$, dan KBK mahasiswa program studi pendidikan matematika jenjang strata satu pada matakuliah geometri ruang.

Secara teori, terdapat beberapa kemiripan karakteristik antara GDL, PjBL dan PBL (Problem Based Learning). Ketiga model pembelajaran tersebut menekankan pada kegiatan pembelajaran yang dapat memfasilitasi peserta didik untuk dapat mengkonstruksi pemahamannya sendiri. Oleh karena itu, hasil penelitian yang menunjukkan keefektifan PBL dapat dianggap relevan dengan penelitian ini. Hasil penelitian Happy dan Widjajanti (2014: 48) menunjukkan bahwa penerapan PBL lebih efektif dibandingkan penerapan metode pembelajaran konvensio- nal ditinjau dari keterampilan berpikir kritis peserta didik. Artinya, penerapan model pembelajaran yang setara atau sejenis dengan PBL berpotensi untuk meningkatkan keterampilan berpikir kritis peserta didik.

Sampai saat ini belum diketahui secara empiris diantara kedua model pembelajaran tersebut manakah model yang paling efektif untuk meningkatkan prestasi belajar (penguasaan materi geometri ruang), kepercayaan diri, dan keterampilan berpikir kritis mahasiswa, sehingga penelitian ini perlu dilakukan. Tujuan penelitian ini yaitu untuk mendeskripsikan keefektifan model GDL dan PjBL, serta perbandingan antara keefektifan model GDL dan PjBL ditinjau dari prestasi belajar, kepercayaan diri, dan keterampilan berpikir kritis mahasiswa pada matakuliah geometri ruang.

Hasil penelitian ini diharapkan dapat memberikan pengalaman kepada peneliti dalam mengelola perkuliahan yang bercirikan model GDL dan PjBL pada matakuliah geometri ruang. Selain itu, diharapkan dapat menjadi contoh inovasi kegiatan pembelajaran pada materi bangun ruang di tingkat perguruan tinggi untuk meningkatkan prestasi belajar, kepercayaan diri, dan keterampilan berpikir mahasiswa program studi pendidikan matematika yang memiliki karakteristik sama atau hampir sama dengan subjek penelitian ini. Diharapkan pula hasil penelitian ini dapat menjadi bekal bagi subjek penelitian ketika kelak menjalankan tugasnya sebagai guru mata pelajaran matematika.

\section{METODE}

Jenis penelitian ini adalah eksperimen semu. Populasi dari penelitian ini adalah seluruh mahasiswa Program Studi Pendidikan Matematika Jenjang S-1 Universitas Ahmad Dahlan Tahun Akademik 2014/2015. Sampel penelitian ini yaitu dua kelas yang ditentukan secara acak dari keempat kelas yang tersedia, yaitu kelas B dan C. Kelas B yang terdiri atas 58 mahasiswa mendapatkan perlakuan model GDL sedangkan Kelas $\mathrm{C}$ yang juga terdiri atas 58 mahasiswa mendapat perlakuan model PjBL.

Kriteria ketuntasan minimal untuk PB adalah skor 65 dari skor maksimal 100 pada posttest. Kriteria ketuntasan minimal untuk KD adalah pencapaian kriteria kepercayaan diri yang baik, yaitu skor 61,21 dari skor maksimal 90 . Kriteria ketuntasan minimal untuk KBK adalah skor 65 dari skor maksimal 100 pada pada posttest. Suatu model pembelajaran dikatakan efektif jika rata-rata skor mahasiswa pada PB, 


\section{Pythagoras, 10 (2), Desember 2015 - 182}

Okky Riswandha Imawan

$\mathrm{KD}$, dan KBK telah mencapai kriteria ketuntasan minimal masing-masing.

Teknik pengumpulan data untuk variabel PB adalah tes. Instrumen pengumpulan datanya adalah soal uraian sesuai indikator pencapaian kompetensi pada matakuliah geometri ruang. Tes pengukur PB diberikan kepada mahasiswa berupa pretest dan posttest. Pretest diberikan sebelum perlakuan model pembelajaran diberikan kepada mahasiswa sedangkan posttest diberikan setelah perlakuan model pembelajaran diberikan kepada mahasiswa. Pretest dan posttest dibuat berdasarkan indikator pencapaian kompetensi yang sama.

Teknik pengumpulan data untuk variabel $\mathrm{KD}$ adalah angket. Instrumen pengumpulan data dari angket adalah pertanyaan yang dilengkapi dengan pilihan jawaban berbentuk skala likert. Sementara itu, teknik pengumpulan data untuk variabel KBK adalah tes. Instrumen pengumpulan datanya adalah soal uraian sesuai dengan beberapa indikator pencapaian kompetensi pada matakuliah geometri ruang yang menuntut penggunaan aspek-aspek keterampilan berpikir kritis. Untuk variabel KBK pun berupa pretest dan posttest.

Hasil estimasi reliabilitas instrumen tes prestasi belajar, angket kepercayaan diri, dan tes keterampilan berpikir kritis berdasarkan hasil ujicoba sebagai berikut.

Tabel 1. Estimasi Reliabilitas Instrumen

\begin{tabular}{ccc}
\hline Instrumen & Reliabilitas & SEM \\
\hline Pretest $\mathrm{PB}$ & 0,671 & 2,11 \\
Posttest $\mathrm{PB}$ & 0,623 & 2,16 \\
KD & 0,778 & 3,83 \\
Pretest $\mathrm{KBK}$ & 0,56 & 1,21 \\
Posttest $\mathrm{KBK}$ & 0,56 & 1,29 \\
\hline
\end{tabular}

Tabel 1 menunjukkan bahwa instrumen pretest prestasi belajar, posttest prestasi belajar, dan kepercayaan diri telah mencapai kriteria reliabilitas yang cukup tinggi sehingga layak untuk digunakan dalam penelitian. Sementara itu instrumen pretest keterampilan berpikir kritis dan posttest keterampilan berpikir kritis belum mencapai kriteria reliabilitas yang cukup tinggi, sehingga dilakukan perbaikan sehingga layak digunakan dalam penelitian.

Sementara itu, hasil validasi isi/konstruk perangkat penelitian menunjukkan bahwa perangkat penelitian, termasuk di dalamnya instrumen penelitian, layak digunakan setelah direvisi sesuai saran dari valodator. Selain itu, hasil validasi konstruk yang didasarkan pada tabel Total Variace Explained, terdapat 6 faktor dari variabel $\mathrm{KD}$ dan mampu mengukur $74,622 \%$ varians untuk variabel tersebut.

Teknik analisis data yang digunakan dalam penelitian ini adalah analisis deskriptif dan inferensial. Analisis deskriptif untuk mendeskripsikan keadaan sebelum dan sesudah pemberian perlakuan pada kedua kelas ditinjau dari masing-masing variabel terikatnya. Analisis inferensial dilakukan untuk mengambil kesimpulan berdasarkan data yang telah diperoleh selama proses penelitian berlangsung. Analisis inferensial ini terdiri atas uji keefektifan dan uji komparasi model pembelajaran matematika.

Data hasil pengukuran $\mathrm{PB}, \mathrm{KD}$, dan KBK dideskripsikan dengan cara membandingkan skor rata-ratanya dengan kriteria ketuntasan minimum yang ditetapkan dalam penelitian ini. Kriteria ketuntasan minimum untuk prestasi belajar dan keterampilan berpikir kritis disesuaikan dengan kriteria ketuntasan minimal yang telah ditetapkan bagi mahasiswa Program Studi Pendidikan Matematika Jenjang S-1 Universitas Ahmad Dahlan, yaitu nilai $\mathrm{C}$ atau nilai 65 . Sementara itu kriteria penilaian kepercayaan diri dalam penelitian ini, dibuat sendiri oleh peneliti sebagai berikut.

\section{Tabel 2. Kriteria Penilaian KD}

\begin{tabular}{cc}
\hline Interval Skor & Kriteria \\
\hline $\mathbf{7 5 , 6} 6 \mathrm{X}$ & Sangat Tinggi \\
$61,2<\mathrm{X} \leq 75,6$ & Tinggi \\
$46,8<\mathrm{X} \leq 61,2$ & Cukup \\
$32,4<\mathrm{X} \leq 46,8$ & Rendah \\
$\mathrm{X} \leq 32,4$ & Sangat Rendah \\
\hline
\end{tabular}

(Diadaptasi dari Widoyoko, 2009, p.238)

Kriteria ketuntasan minimal untuk variabel KD adalah tinggi (skor 61,2), artinya seluruh subjek penelitian yang telah mendapatkan perlakuan minimal termasuk ke dalam kriteria KD yang tinggi.

Berikut adalah asumsi dasar yang harus terpenuhi sebelum melakukan analisis inferensial: (1) observasi-observasi pada variabel terikat berdistribusi normal multivariat di masing-masing kelompok; (2) matriks kovarians populasi untuk variabel terikat harus sama (Stevens, 2009, p.218). untuk memeriksa asumsi normalitas, yaitu dengan menggunakan kriteria $\chi^{2}$ yaitu jika sekitar $50 \%$ nilai $d_{i}{ }^{2}<X^{2}{ }_{p}(0,5)$ (Johnson \& Wichren (2007, pp.182-183), maka dapat dikatakan bahwa data tersebut berasal dari populasi yang berdistribusi normal multivariat. Sedangkan kelengkungan menunjukkan penyimpangan dari normalitas. Uji normalitas multivariat yang digunakan dalam penelitian ini yaitu 
dengan menghitung jarak Mahalanobis dengan rumus $d_{i}^{2}=\left(X_{i}-\bar{X}\right)^{\prime} S^{-1}\left(X_{i}-\bar{X}\right) \leq X_{2}^{2}(0,5)$.

Jika $50 \%$ dari subjek penelitian terletak pada $d_{i}^{2} \leq X_{(p: 0,5)}^{2}$, maka data berasal dari populasi yang berdistribusi normal multivariat (Johnson \& Wichern, 2007, p.183). Uji normalitas multivariat terhadap data pretest $\mathrm{PB}$, $\mathrm{KD}$, dan KBK subjek penelitian sebelum mendapatkan perlakuan model GDL menunjukkan bahwa $\chi_{0,5(3)}^{2}=2,365$ dan terdapat 29 dari 58 subjek penelitian yang nilai $d_{i}^{2}$-nya kurang dari 2,365 , artinya sebesar $50 \%$ nilai $d_{i}^{2}<\chi_{0,5(3)}^{2}$. Dengan persentase tepat sebesar 50\% maka dapat disimpulkan bahwa kemampuan awal subjek penelitian sebelum mendapatkan perlakuan model GDL berdistribusi normal multivariat.

Uji normalitas multivariat terhadap data pretest subjek penelitian sebelum mendapatkan perlakuan model PjBL menunjukkan bahwa $\chi_{0,5(3)}^{2}=2,365$ dan terdapat 30 dari 58 subjek penelitian yang nilai $d_{i}^{2}$-nya kurang dari 2,365 , artinya sebesar $51,72 \%$ nilai $d_{i}^{2}<\chi_{0,5(3)}^{2}$. Dengan persentase disekitar $50 \%$, yaitu hanya lebih $1,72 \%$, maka dapat disimpulkan bahwa kemampuan awal subjek penelitian sebelum mendapatkan perlakuan model PjBL berdistribusi normal multivariat.

Uji normalitas multivariat terhadap data posttest subjek penelitian setelah mendapatkan perlakuan model GDL menunjukkan bahwa $\chi_{0,5(3)}^{2}=2,365$ dan terdapat 34 dari 58 subjek penelitian yang nilai $d_{i}^{2}$-nya kurang dari 2,365 , artinya sebesar $58,62 \%$ nilai $d_{i}^{2}<\chi_{0,5(3)}^{2}$. Dengan persentase disekitar $50 \%$, yaitu hanya lebih $8,62 \%$, maka dapat disimpulkan bahwa kemampuan subjek penelitian ( $\mathrm{PB}, \mathrm{KD}$, dan $\mathrm{KBK}$ ) setelah mendapatkan perlakuan model Guided Discovery Learning berdistribusi normal multivariat.

Uji normalitas multivariat terhadap data posttest subjek penelitian setelah mendapatkan perlakuan model PjBL menunjukkan bahwa $\chi_{0,5(3)}^{2}=2,365$ dan terdapat 31 dari 58 subjek penelitian yang nilai $d_{i}^{2}$-nya kurang dari 2,365 , artinya sebesar $53,45 \%$ nilai $d_{i}^{2}<\chi_{0,5(3)}^{2}$. Dengan persentase disekitar $50 \%$, yaitu hanya lebih $3,45 \%$, maka dapat disimpulkan bahwa kemampuan subjek penelitian setelah mendapatkan perlakuan model GDL berdistribusi normal multivariat

Sementara itu, uji homogenitas dilakukan untuk menguji kesamaan matriks varians- kovarians dari veriabel terikat antara dua kelas. Uji homogenitas terhadap semua variabel terikat, yaitu PB, KD, dan KBK mahasiswa dilakukan bersamaan menggunakan Uji Box's M. Jika nilai signifikansi (probabilitas) lebih besar dari 0,05 maka dapat disimpulkan bahwa matriks varians-kovarians pada variabel terikat antara dua kelas adalah homogen (Huberty \& Olejnik, 2006, p.41).

Setelah melewati proses uji asumsi, maka dilanjutkan dengan uji keefektifan setiap model pembelajaran ditinjau dari setiap variabel terikat dengan one sample $t$ test dan uji perbedaan antara keefektifan kedua model pembelajaran dengan uji Multivariate Analysis of Variance (MANOVA) $T^{2}$ Hotelling (Stevens, 2009, p.148). Taraf signifikansi yang digunakan pada uji keefektifan dan perbedaan keefektifan adalah 0,05 .

\section{HASIL DAN PEMBAHASAN}

\section{Hasil Penelitian}

Penelitian ini dilaksanakan dengan diawali pemberian pretest kepada kedua kelompok subjek penelitian, yaitu Kelas B dan C. Pretest yang dimaksud adalah pretest $\mathrm{PB}, \mathrm{KD}$, dan KBK. Selanjutnya model Guided Discovery Learning diterapkan selama tujuh pertemuan pada Kelas B dan model Project Based Learning pun diterapkan selama tujuh pertemuan pada Kelas C. Dalam setiap pertemuan, peneliti bertindak sebagai dosen, sedangkan dosen matakuliah Geometri Ruang yang mengasuh kedua kelas tersebut bertindak sebagai observer. Hasil observasi menunjukkan bahwa peneliti telah berhasil menerapkan kedua model pembelajaran dengan baik, yaitu lebih dari $80 \%$. Sementara itu hasil pretest dan posttest terhadap subjek penelitian sebagai berikut.

Tabel 3. Rerata Kelas PBP dan PBM

\begin{tabular}{ccccc}
\hline Variabel & \multicolumn{2}{c}{ GDL } & \multicolumn{2}{c}{ PjBL } \\
\cline { 2 - 5 } terikat & Pretest & Posttest & Pretest & Posttest \\
\hline PB & 47,84 & 86,97 & 54,31 & 85,28 \\
KD & 60,66 & 62,78 & 61,72 & 62,69 \\
KBK & 15,34 & 71,98 & 20,69 & 73,88 \\
\hline
\end{tabular}

Dari Tabel 3 dapat diketahui bahwa penerapan kedua model pembelajaran dapat meningkatkan $\mathrm{PB}, \mathrm{KD}$, dan KBK mahasiswa pada matakuliah geometri ruang. Setelah asumsi normalitas multivariat dan homogenitas terpenuhi, berikut ini hasil uji MANOVA terhadap hasil pretest subjek penelitian yang disajikan pada Tabel 4. 
Tabel 4. Hasil Uji Two-Group MANOVA

\begin{tabular}{cccc}
\hline Statistik Uji & Value & F & Sig. \\
\hline Hotelling's Trace & 0,066 & 2,470 & 0,066 \\
\hline
\end{tabular}

Tabel 4 menunjukkan bahwa nilai $\mathrm{F}$ adalah 2,470 dan nilai signifikansi adalah 0,066. Karena nilai signifikansi, 0,066 > 0,05, maka dapat disimpulkan bahwa tidak terdapat perbedaan kemampuan awal (PB, KD, dan KBK) antara dua kelompok subjek penelitian sebelum perlakuan model GDL dan model PjBL.

Setelah asumsi normalitas multivariat dan homogenitas terpenuhi, berikut ini hasil uji-t terhadap hasil posttest subjek penelitian atau uji keefektifan setiap model pembelajaran ditinjau dari setiap variabel terikat yang disajikan pada Tabel 5.

Tabel 5. Hasil Uji Keefektifan Setiap Model

\begin{tabular}{cccc}
\hline Kelompok & Variabel & t & Sig. \\
\hline GDL & PB & 14,698 & 0,000 \\
& KD & 1,765 & 0,041 \\
& KBK & 3,340 & 0,000 \\
\hline PjBL & PB & 12,560 & 0,000 \\
& KD & 1,963 & 0,027 \\
& KBK & 3,661 & 0,000 \\
\hline
\end{tabular}

Tabel 5 menunjukkan bahwa setiap nilai sig. dari setiap variabel terikat baik pada perlakuan model GDL maupun PjBL < 0,05, maka dapat disimpulkan bahwa setiap model pembelajaran efektif ditinjau dari setiap variabel terikat. Sementara itu, berikut ini hasil uji MANOVA terhadap hasil posttest subjek penelitian yang disajikan pada Tabel 6 .

Tabel 6. Hasil Uji Two-Group MANOVA

\begin{tabular}{cccc}
\hline Statisitik Uji & Value & F & Sig. \\
\hline Hotelling's Trace & 0,010 & 0,380 & 0,768 \\
\hline
\end{tabular}

Tabel 6 menunjukkan bahwa nilai $\mathrm{F}$ adalah 0,380 dan nilai signifikansi adalah 0,768. Karena nilai signifikansi, 0,768>0,05, maka dapat disimpulkan bahwa tidak terdapat perbedaan keefektifan model GDL dan PjBL ditinjau dari $\mathrm{PB}, \mathrm{KD}$, dan KBK mahasiswa.

\section{Pembahasan}

Hasil analisis data menunjukkan bahwa tidak terdapat perbedaan kemampuan awal (PB, $\mathrm{KD}$, dan KBK) antara dua kelompok subjek penelitian sebelum perlakuan model GDL dan PjBL. Hal ini diperkirakan karena kedua kelompok subjek penelitian (Kelas B dan C) telah dibentuk secara random oleh Program Studi
Pendidikan Matematika Universitas Ahmad Dahlan. Keterangan ini diperoleh dari wawancara terhadap Ketua Program Studi Pendidikan Matematika Universitas Ahmad Dahlan. Hal ini juga diperkirakan karena kedua kelompok subjek penelitian tersebut mendapatkan pengalaman yang hampir sama ketika mengikuti perkuliahan matakuliah Geometri Bidang, baik dari segi materi maupun dari segi tes yang dilaksanakan untuk matakuliah tersebut. Keterangan ini diperoleh dari wawancara terhadap dosen yang bertindak sebagai Penanggung Jawab Keilmuan matakuliah Geometri Universitas Ahmad Dahlan.

Ditinjau dari segi materinya, sumber belajar yang digunakan oleh kedua kelompok subjek penelitian berupa buku Geometri Bidang yang sama. Berdasarkan kurikulum yang berlaku di Universitas Ahmad Dahlan, diketahui bahwa matakuliah Geometri Bidang merupakan matakuliah prasyarat dari matakuliah Geometri Ruang (matakuliah dalam penelitian ini). Ditinjau dari segi tes, soal tes ujian tengah semester maupun ujian semester matakuliah Geometri Ruang yang dibuat oleh beberapa dosen pengampu mata kuliah tersebut divalidasi oleh orang yang sama yaitu penanggung jawab keilmuan matakuliah geometri, sehingga indikator yang hendak dicapai melalui tes dan tingkat kesukarannya relatif sama. Kedua alasan tersebut yang diperkirakan memberikan dampak yang besar terhadap tidak adanya perbedaan kemampuan awal dua kelompok subjek penelitian.

Hasil analisis data menunjukkan bahwa model GDL efektif ditinjau dari PB mahasiswa. Hal ini diperkirakan karena terdapat fase-fase model GDL yang memfasilitasi mahasiswa untuk dapat menguasai dan memahami konsep geometri ruang. Pada Fase 2, yaitu Fase Terbuka, Dosen membimbing mahasiswa melalui pertanyaan-pertanyaan pada Lembar Kegiatan Mahasiswa (LKM) yang mengarahkan mahasiswa untuk mencari informasi yang dibutuhkan untuk menemukan suatu konsep. Pada Fase 3, yaitu Fase Konvergen, Dosen membimbing mahasiswa untuk menggunakan informasi yang diperoleh untuk menemukan suatu konsep. Pada Fase 2 dan 3 tersebut Dosen hanya memberikan bimbingan seperlunya, sehingga mahasiswa-lah yang berperan besar dalam mengkonstruksi sendiri pemahamannya terhadap suatu konsep. Dengan mengkonstruksi sendiri pemahamannya maka konsep tersebut lebih bertahan lama dalam benak mahasiswa. 


\section{Pythagoras, 10 (2), Desember 2015 - 185}

Okky Riswandha Imawan

Selain kedua fase tersebut, terdapat fase lain yang juga diperkirakan berpengaruh terhadap penguasaan mahasiswa terhadap materi atau konsep geometri ruang yang telah dipelajari, yaitu Fase 4. Di dalam Fase 4 atau Fase Penutup dan Penerapan, terdapat kegiatan dimana mahasiswa mengerjakan tes individu, dan kegiatan ini dilaksanakan di setiap pertemuan. Kegiatan tersebut membuat mahasiswa terbiasa dan terlatih untuk mengerjakan soal atau menyelesaikan masalah geometri ruang. Ketiga fase tersebut yang diperkirakan memberikan dampak yang besar terhadap efektifnya model GDL ditinjau dari prestasi belajar mahasiswa. Hasil analisis ini juga didukung oleh beberapa penelitian yang telah dijelaskan pada bagian pendahuluan artikel ini, diantaranya penelitian dari Udo (2011, p.238), Prihantomo (2012, p.x), serta Akanmu \& Fajemidagba (2013, p.85).

Hasil analisis data menunjukkan bahwa model GDL efektif ditinjau dari KD mahasiswa. Hal ini diperkirakan karena terdapat fase-fase model GDL yang dapat meningkatkan kepercayaan diri mahasiswa. Pada Fase 2, yaitu Fase Terbuka, dosen membimbing mahasiswa melalui pertanyaan-pertanyaan pada LKM agar mahasiswa mampu menuliskan pendapatnya sendiri mengenai hal-hal yang berhubungan dengan geometri ruang yang sedang dipelajari. Kegiatan ini dilaksanakan di setiap pertemuan, sehingga mahasiswa terbiasa atau terlatih untuk mengungkapkan pendapatnya. Selain itu, pada Fase 4, yaitu Fase Penutup dan Penerapan, seperti yang telah dijelaskan sebelumnya, mahasiswa terlatih untuk mengerjakan soal atau masalah geometri ruang. Hal ini pun diperkirakan dapat meningkatkan kepercayaan diri mahasiswa jika dihadapakan dengan tugas atau tes geometri ruang. Kedua fase tersebut yang diperkirakan memberikan dampak yang besar terhadap efektifnya model GDL ditinjau KD mahasiswa. Hasil analisis ini juga didukung oleh beberapa penelitian yang dilakukan oleh Tran, Nguyen, Bui, \& Phan (2014, p.56).

Hasil analisis data menunjukkan bahwa model GDL efektif ditinjau dari KBK mahasiswa. Hal ini sesuai dengan hasil penelitian yang dilakukan oleh Sulistyowati, Widodo, \& Sumarni $(2012$, p.) yang menunjukkan bahwa model GDL dapat meningkatkan keterampilan pemecahan masalah peserta didik, dimana keterampilan pemecahan masalah dan KBK sama-sama merupakan jenis keterampilan berpikir tingkat tinggi.
Selain itu, hal ini diperkirakan karena terdapat fase model GDL yang dapat melatih KBK mahasiswa. Pada Fase 2, yaitu Fase Terbuka, seperti telah dijelaskan sebelumnya, dosen membimbing mahasiswa melalui pertanyaanpertanyaan pada LKM, yang mana pertanyaanpertanyaan tersebut menuntut KBK mahasiswa. Pertanyaan-pertanyaan tersebut melatih mahasiswa untuk mampu menilai kebenaran dari halhal yang berkaitan dengan konsep yang dipelajari. Fase tersebut yang diperkirakan memberikan dampak yang besar terhadap efektifnya model GDL ditinjau dari KBK mahasiswa, meskipun tidak menutup kemungkinan bahwa fase-fase lain yang mempengaruhi penguasaan mahasiswa terhadap konsep atau materi geometri ruang juga memberikan dampak positif terhadap keterampilan berpikir kritis mahasiswa.

Hasil analisis data menunjukkan bahwa model PjBL efektif ditinjau dari PB mahasiswa. Hal ini sesuai dengan hasil penelitian Filcik, Bosch, Pederson, \& Haugen (2012, p.1) yang menunjukkan bahwa model pembelajaran tersebut efektif ditinjau dari aspek pengetahuan konseptual. Selain itu, hal ini diperkirakan karena terdapat fase-fase model PjBL yang memfasilitasi mahasiswa untuk dapat menguasai dan memahami konsep geometri ruang. Pada Fase 4, yaitu Fase Mengumpulkan dan mengolah informasi, mahasiswa mengumpulkan informasi yang dibutuhkan untuk memahami konsep yang dipelajari sekaligus untuk mampu melaksanakan proyek. Dosen menyediakan sumber informasi yang dibutuhkan atau dapat pula berupa kegiatan pada LKM agar mahasiswa dapat mengumpulkan sekaligus mengolah informasi. Meskipun tidak sebanyak fase-fase model GDL yang memberikan dampak positif terhadap prestasi belajar mahasiswa, tetapi kenyataan menunjukkan bahwa Fase 4 dari model PjBL mampu memberikan dampak positif terhadap efektifnya model $\mathrm{PjBL}$ ditinjau dari prestasi belajar mahasiswa.

Hasil analisis data menunjukkan bahwa model PjBL efektif ditinjau dari KD mahasiswa. Hal ini diperkirakan karena terdapat fase-fase model PjBL yang dapat meningkatkan KD mahasiswa. Pada Fase 2, yaitu Fase Mengidentifikasi masalah, dosen menyediakan kegiatan pada LKM agar mahasiswa mampu memilih dan mendesain proyek yang akan dikerjakan sesuai dengan kemampuan yang dimilikinya. Hal ini diperkirakan dapat melatih kepercayaan mahasiswa terhadap kemampuannya, memilih proyek sesuai kehendaknya, sekaligus bertanggung 
jawab terhadap proyek yang telah dipilih. Selain itu, pada Fase 6, yaitu fase menilai dan memperbaiki produk, mahasiswa mempresentasikan produk yang telah dibuat dihadapan rekan satu kelas. Pada kegiatan ini mahasiswa ditintut untuk dapat mempertanggungjawabkan produk buatannya.

Selanjutnya pada Fase 7, yaitu Fase Finalisasi dan Publikasi Produk, Dosen memberikan kesempatan kepada mahasiswa untuk memperbaiki produknya jika masih terdapat kekurangan. Kegiatan ini melatih mahasiswa untuk tetap berusaha memperbaiki produk buatannya agar menjadi lebih baik. Ketiga fase tersebut yang diperkirakan memberikan dampak yang besar terhadap efektifnya model $\mathrm{PjBL}$ ditinjau dari KD mahasiswa.

Hasil analisis data menunjukkan bahwa model PjBL efektif ditinjau dari KBK mahasiswa. Hal ini diperkirakan karena terdapat fase model PjBL yang dapat melatih KBK mahasiswa. Pada Fase 2, yaitu Fase Mengidentifikasi Masalah, seperti telah dijelaskan sebelumnya, pada kegiatan ini, mahasiswa berusaha mengidentifkasi masalah yang diberikan dosen, kemudian memilih proyek yang terbaik untuk menyelesaikan masalah tersebut. Pada kegiatan ini mahasiswa dilatih menggunakan keterampilan berpikir kritisnya untuk menentukan tindakan terbaik untuk menyelesaikan suatu masalah. Hasil analisis data ini didukung oleh kajian teoritis yang dilakukan oleh Masek \& Yamin (2011, p.219).

Hasil analisis data menunjukkan bahwa tidak terdapat perbedaan keefektifan model GDL dan model PjBL ditinjau dari PB, KD, dan KBK mahasiswa. Kesimpulan ini bertentangan dengan hasil kajian teori dan hasil analisis deskriptif yang lebih mengunggulkan model GDL. Hal ini diperkirakan karena beberapa keterbatasan penelitian. Salah satunya yaitu meskipun LKM model GDL dan LKM model PjBL telah dibuat sesuai dengan fase masingmasing model tersebut, tetapi kandungan materinya tetap sama, yaitu berasal dari sumber ilmu atau informasi geometri ruang yang sama. Hasil analisis data menunjukkan bahwa adanya perbedaan fase penerapan kedua model tidak mampu membuat keefektifan kedua model berbeda secara signifikan.

Meskipun tidak terdapat perbedaan keefektifan kedua model, akan tetapi hasil analisis data menunjukkan bahwa model GDL dan PjBL sama-sama efektif ditinjau dari $\mathrm{PB}, \mathrm{KD}$, dan KBK mahasiswa. Dengan demikian kedua model tersebut layak untuk diterapkan dalam perkuliahan Geometeri Ruang dan kepada mahasiswa yang memiliki karakteristik setara dengan mahasiswa yang menjadi subjek penelitian ini.

\section{SIMPULAN DAN SARAN}

\section{Simpulan}

Hasil penelitian menunjukkan bahwa, ditinjau dari prestasi belajar, kepercayaan diri, dan keterampilan berpikir kritis mahasiswa diketahui bahwa penerapan model GDL pada matakuliah Geometri Ruang efektif, penerapan model PjBL pada matakuliah Geometri Ruang efektif, dan tidak terdapat perbedaan keefektifan model GDL dan model PjBL pada matakuliah Geometri Ruang.

\section{Saran}

Berasarkan kajian teori dan pengalaman selama menerapkan model GDL pada perkuliahan diketahui bahwa model tersebut sebaiknya diterapkan kepada mahasiswa yang memiliki kepandaian yang baik. Hal ini karena model ini memfasilitasi mahasiswa untuk mampu menemukan dan mengkonstruksi konsep geometri ruang secara mandiri. Dosen hanya memberikan bimbingan sesuai kebutuhan mahasiswa. Sebagian besar konsep atau materi geometri ruang dipelajari sendiri oleh mahasiswa. Mahasiswa yang kepandaiannya kurang baik cenderung kesulitan dan membutuhkan waktu yang lama untuk mampu menemukan atau mengkonstruksi konsep geometri ruang.

Model PjBL sebaiknya diterapkan kepada mahasiswa yang aktif dan memiliki keterampilan yang baik. Hal ini karena model ini memfasilitasi mahasiswa untuk mampu mempelajari konsep atau materi geometri ruang sekaligus terampil dalam membuat produk untuk menyelesaikan suatu permasalahan dengan cepat dan tepat. Mahasiswa yang pasif cenderung kesulitan untuk membagi konsentrasinya antara mempelajari konsep dan membuat produk, akibatnya mahasiswa tersebut mampu mempelajari konsep dengan baik namun produk yang dibuat kurang baik, ataupun sebaliknya.

Berdasarkan hasil wawancara terhadap mahasiswa yang menjadi subjek penelitian, sebagian mahasiswa merasa bosan jika setiap pertemuan hanya menerapkan model pembelajaran yang sama. Oleh karena itu, dalam perkuliahan Geometri Ruang perlu adanya variasi penerapan model pembelajaran, yaitu variasi antara model GDL dan PjBL. 


\section{DAFTAR PUSTAKA}

Abidin, Y. (2014). Desain sistem pembelajaran dalam konteks kurikulum 2013. Bandung: PT Refika Aditama.

Akanmu, M., \& Fajemiddagba, M. O. (2013). Guided-discovery learning strategies and senior school students performance in mathematics in ejigbo, Nigeria. Journal of Education and Practice, Volume 4, No 12, PP 82-90.

Arends, R. I., \& Kilcher, A. (2010). Teaching for student learning. New York, NY: Routladge Taylor and Francis Group.

Boyd, D., \& Bee, H. (2009). Lifespan development fifth edition. Boston: Pearson Education.

Epstein, R. L., \& Kernberger, C. (2006). Critical thinking. Toronto: Thomson Wadsworth.

Feldman, D. A. (2010). Berpikir Kritis. (Terjemahan Ati Cahayani) Jakarta: PT Indeks.

Filcik, A. et al. (2012). The effects of projectbased learning $(\mathrm{PjBL})$ approach on the achievement and efficacy of high school mathematics students: a longitudinal study investigating the effects of pjbl approach in mathematics education. Proceedings of The National Conference On Undergraduate Research (NCUR), 29-31 Maret 2012. Odgen Utah: Weber State University, Utah.

Gambrill, E., \& Gibbs, L. (2009). Critical thinking for healping professional. Oxford: Oxford University Press.

Ghufron, M. N., \& Risnawati S, R. (2010). Teori-teori psikologi. Yogyakarta: Arruzz Media.

Glazer, E. (2001). Using internet primary sources to teach critical thinking skills in mathematics. Westpost: Greenwood Press.

Happy, N., \& Widjajanti, D. (2014). Keefektifan PBL ditinjau dari kemampuan berpikir kritis dan kreatif matematis, serta selfesteem siswa SMP. Jurnal Riset Pendidikan Matematika, 1(1), 48-57. doi:http://dx.doi.org/10.21831/jrpm.v1i1. 2663
Hudojo, H. (1988). Mengajar belajar matematika. Jakarta: Departemen Pendidikan dan Kebudayaan.

Huberty C.J., \& Olejnik, S. (2006). Applied MANOVA and discriminant analysis. Upper Saddle River, New Jersey: John Wiley \& Sons, Inc.

Johnson, R., \& Wichern, D. W. (2007). Applied multivariate statistical analysis $6^{\text {th }}$ edition. New Jersey, NJ: Pearson Prentice Hall.

Linguistika, Y., Listyani, E., \& Retnawati, H. (2013). Peta penguasaan materi matematika guru sma dan hubungannya dengan prestasi belajar siswa. Seminar Nasional Matematika dan Pendidikan Matematika. P-87.

Masek, A., \& Yamin, S. (2011). The effect of problem based learning on critical thinking ability: a theoretical and empirical review. International Review of Social Sciences and Humanities, Volume 2, No 1, PP 215-221.

McElmeel, S. L. (2002). Character education. Colorado: Greenwood Publishing Group, Inc.

McPheat, S. (2010). Personal confidence \& motivation. UK: MTD Training \& Ventus Publishing.

Nitko, A. J., \& Brookhart, S. (2011). Educational assessment of student sixth edition. Boston: Pearson Education Inc.

Ozdemir, E. (2006). An investigation on the effects of project-based learning on students' achievement and attitude toward geomerty. Tesis Magister, Middle East Technical University.

Prihantomo, H. (2012). The quality improvement on integral mathematics learning by guided discovery learning model at class xii building technique salatiga academic year 2011/2012. Tesis Magister, Universitas Muhammadiyah Semarang.

Starkey, L. B. (2010). Critical thinking skills success in 20 minutes a day 2 nd edition. New York, NY: LearningExpress.

Stevens, J. P. (2009). Applied multivariate statistics for the social sciences $5^{\text {th }}$ 


\section{Pythagoras, 10 (2), Desember 2015 - 188}

Okky Riswandha Imawan

edition. New York, NY: Routledge Taylor $\&$ Francis Group.

Sudjana, N. (1992). Penilaian hasil proses belajar mengajar. Bandung: PT Remaja Rosdakarya.

Sulistyowati, N., Widodo, A. T., \& Sumarni, W. (2012). Efektifitas model pembelajaran guided discovery learning terhadap kemampuan pemecahan masalah kimia. Chemistry in Education, Volume 2, No 1, Agustus 2012, PP 50-55. Universitas Negeri Semarang.

Syah, M. (2014). Psikologi pendidikan dengan pendekatan baru. Bandung: PT Remaja Rosda Karya.

Taghva, F. et al. (2014). Studying the relationship between critical thinking skills and students' educational achievement (eghlid universities as case study). International Letter of Social and Humanistic Sciences, Volume 25, PP 1825.
Tan, A. (2007). Creativity. Singapore: World Scientific.

Thomas, J. W. (2000). A review of research on project based learning. California: The Autodesk Foundation.

Tran, T. et al. (2014). Discovery learning with the help of the geogebra dynamic geometry software. International Journal of Learning, Teaching, and Educational Research, Volume 7, No 1, Agustus 2014, PP 44-57.

Udo, M. E. (2011). Effects of problem-solving, guided-discovery, and expository teaching strategies on students' performance in redox reaction. An International Multidisciplinary Journal, Volume 5, No 21, Juli 2011, PP 231-241. Etiopia.

Widoyoko, E. P. (2009). Evaluasi program pembelajaran. Yogyakarta: Pustaka Pelajar.

Winkel, W. S. (1996). Psikologi pembelajaran. Jakarta: PT Grasindo. 